\title{
Chemical Constituents of Dissotis perkinsiae (Melastomaceae) and Their Antimicrobial Activity
}

\author{
Tchebemou Bakang Bruno ${ }^{1}$, Nganso Ditchou Yves Oscar ${ }^{2}$, Soh Désiré ${ }^{3}$, Zondegoumba Nkwengoua Tchouboun \\ Ernestine $^{1}$, Toghueo Kouipou Rufin Marie ${ }^{4}$, Sidjui Sidjui Lazare ${ }^{1}$, Fekam Boyom Fabrice $^{4}$, Schneider Bernd ${ }^{5}$, \\ Nyasse Barthélémy ${ }^{1 *}$
}

${ }^{1}$ Department of Organic Chemistry, Faculty of Science, University of Yaounde I, P.O.Box:812 Yaounde, Cameroon., ${ }^{2}$ Department of Chemistry, Faculty of Science, University of Maroua, P.O.Box: 814 Maroua, Cameroon., ${ }^{3}$ Department of Organic Chemistry, Higher Teachers Training College, University of Bamenda, P.O.Box: 39 Bambili, Cameroon., ${ }^{4}$ Department of Biochemistry, Faculty of Science, University of Yaoundé I, P.O.Box: 812 Yaoundé, Cameroon., ${ }^{5}$ Max Plant Institute for Chemical Ecology, Beutenberg Campus, Hans-Knol.8, D-07745 Jena, Germany.

\section{ARTICLE INFO}

Article history:

Received on: 19/12/2015

Revised on: 22/02/2016

Accepted on: 10/04/2016

Available online: 30/08/2016

\section{Key words:}

Dissotis perkinsiae, Phytochemistry,

Antimicrobial activity.

\begin{abstract}
The phytochemical study of the Methanol/dichloromethane extract of the leaves of Dissotis perkinsiae led to the isolation and identification seven compounds: Ursolic acid (1); Sitosterol- $\beta$-D-glucoside (2); Isoquercitrin (3); Quercetin-3-O- $\beta$-galactoside (4);Kaempferol-3-O- $\beta$-D-glucoside (5); Kaempferol-7-O- $\beta$-D-glucoside (6); Trans-Tiliroside (7). Their structures were elucidated on the basis of spectroscopic analysis and by comparison of their spectral data with those reported in the literature. The results of antimicrobial activity indicated that the MIC vary from $>0.5$ to $0.00078 \mathrm{mg} / \mathrm{mL}$ on yeasts and from $>0.5$ to $0.25 \mathrm{mg} / \mathrm{mL}$ on bacteria. Sitosterol $\beta$-Dglucoside was the most active with the broad spectrum $(\mathrm{MIC}=0.125 \mathrm{mg} / \mathrm{mL}$ on $C$. albicans, $\mathrm{MIC}=0.0625 \mathrm{mg} / \mathrm{mL}$ on $C$. kruseiand MIC $=0.0078 \mathrm{mg} / \mathrm{mL}$ on $C$. parapsilosis). Kaempferol-7-O- $\beta$-D-glucoside was the most active on $C$. krusei $(\mathrm{MIC}=0.0039 \mathrm{mg} / \mathrm{mL}$ ). The anti yeat activity of Sitosterol- $\beta$-D-glucoside and Kaempferol-7-O- $\beta$ D-glucoside were better thanfluconazole $(0.032 \mathrm{mg} / \mathrm{mL}$ ) on C. parapsilosis (MIC $0.0078 \mathrm{mg} / \mathrm{mL}$ ) and C. krusei $(0.0039 \mathrm{mg} / \mathrm{mL})$ respectively. Sitosterol- $\beta$-D-glucoside and Trans-Tiliroside showed weak inhibitotry activity against $S$. enteric and $S$. aureus with MIC value of $0.5 \mathrm{mg} / \mathrm{mL}$. Respectively this inhibitory effect was lower activities observed with Chloremphenicol and Ampicillin $(0.000488 \mathrm{mg} / \mathrm{mL})$. The results of this study suggest that Dissotis perkinsiae represent an untapped source of compounds with potential antimicrobial activity that could be explored in the development of new therapeutic natural products.
\end{abstract}

\section{INTRODUCTION}

Application of natural products with therapeutic properties is as old as human civilization. These products have been exploited for human use from thousands of years, and plants have been the chief source of compounds used for medicine. In fact, plants represent the largest sources of active substances that can be used in medical therapy due to the large structural diversity that these metabolites exhibit, being perhaps the oldest

\footnotetext{
* Corresponding Author

Email:bnyasse@yahoo.com
}

source of medicines for man (Brandão et al., 2010). Drugs derived from natural products with antibacterial, antifungal, anticoagulant, antiparasitic, immune suppressive and anticancer activity are capable of treating $87 \%$ of categorized human diseases (Newman et al., 2003). Of the 520 new drugs approved between 1983 and 1994, $39 \%$ were natural products or derived from natural products and $60-80 \%$ of antimicrobial were derived from natural products (Cragg et al., 1997). Such data justifies work in the area of natural products, particularly in view of its importance in the search for new drugs against bacterial and fungal infections. The genus Dissotis, member of the Melastomaceae family is one of the most important genus in tropical forests which represent about 140 species in Africa (Loigier, 1994). 
They are climbing shrubs, shrubs or small trees of up to 2 $\mathrm{m}$, and are found in countries as Democratic Republic of Congo, Benin, Nigeria, Cote d'Ivoire, Togo and Cameroon (Maluma, 2005). Several species are used in folk medicine, mainly as antidiarrheic, antimicrobial, skin diseases, antioxidant, fever, malaria, cleansing, antitumoral, anti-rheumatic, and anti-inflammatory agents, as well as to lower blood cholesterol. Dissotis perkinsiae, found in tropical areas of Nigeria, Togo and Cameroon is a shrub with the height of 90-150 cm. The leaves are purple or pink with a diameter of about $10.5 \mathrm{~cm}$ (Hutchinson and Dalziel, 1954). It is used in traditional medicine for the treatment of the skin diseases and malaria (Haxaire, 1979). In previous studies, some triterpenoïds, flavonoïds and tannins were identified (Ndjateu et al, 2014).Such data have encouraged the investigation of Dissotis perkinsiae with the aim to search for compounds with antibacterial and antifungal activities.

\section{MATERIAL AND METHODS}

\section{General experimental procedures}

Mass spectral data [Electrospray ionization mass spectrometry (ESI-MS)] weremeasured on a Waters Synapt HDMS spectrometer. NMR spectra were recorded with aVarian spectrometer at $400 \mathrm{MHz}$. Chemical shifts $(\delta)$ were quoted in parts per million (ppm) from the internal standard tetramethylsilane (TMS). Deuterated solvents dimethyl sulfoxide (DMSO-d6), and chloroform $\left(\mathrm{CDCl}_{3}\right)$ were used as solvents for the NMR experiments. Column chromatography was performed on silica gel 60 [(0.2-0.5 mm) and $(0.2-0.063 \mathrm{~mm})]$ mesh (Sigma-Aldrich, Germany). Pre-coated silica gel 60 F254 thin layer chromatography (TLC) plates (Merck, Germany) were used for monitoring fractions and spots were detected with UV light (254 and $365 \mathrm{~nm})$ and then sprayed with $30 \%$ sulphuric acid $\left(\mathrm{H}_{2} \mathrm{SO}_{4}\right)$ followed by heating to $110{ }^{\circ} \mathrm{C}$.

\section{Sample collection}

Dissotis perkinsiae leaves were harvested in BangouaCameroon, (May, 2012) and identified by Mr. Victor Nana (Plant taxonomist) of the Cameroon National Herbarium (HNC), where a voucher specimens are deposited (24719/SRF/Cam). Then, leaves were dried at room temperature and powdered.

\section{Extraction and isolation}

$1700 \mathrm{~g}$ of powdered leaves were extracted by maceration in seven liters (7L) of dichloromethane/methanol (DCM/MeOH, $1: 1, \mathrm{v} / \mathrm{v})$ mixture at room temperature for $72 \mathrm{~h}$. The filtrate was concentrated in rota vapor (Büchi R-200) under reduce pressure at $65{ }^{\circ} \mathrm{C}$ to yield $240 \mathrm{~g}$ of extract. Dried extract was dissolved in water and successively extracted with hexane, dichloromethane, ethyl acetate and n-butanol. All these extracts collected were preserved for chemical analysis.

Hexane fraction $(18.0 \mathrm{~g})$ was subjected to vacuum liquid chromatography (VLC) over TLC grade silica gel (GF254) and eluted with $n$-hexane/AcOEt mixture with increasing polarity from $n$-hexane to AcOEt. Ten fractions (F1-F10) were obtained after combining subfractions according to their TLC profiles. Fraction F2 obtained at a polarity of n-hexane/AcOEt (85:15), yield Ursolic acid (2,15mg). Fraction F8 obtained with n-hexane/AcOEt (20:80) was subjected to other column chromatography with nhexane/AcOEt increasing polarity to yield Sitosterol-3-O- $\beta$-Dglucoside (3.26 mg).

The ethyl acetate soluble fraction was subjected to column chromatography (CC) over silica gel $(4 \times 150 \mathrm{~cm}, 250 \mathrm{~g}$, $70-230$ mesh) and eluted with $n$-hexane/AcOEt mixture with increasing polarity to afford 66 subfractions combined in 6 fractions (F1-F6) according to their TLC profiles. Fraction F5 was subjected to other column chromatography to yield Isoquercitrin (4.17 mg), Quercetin-3-O- $\beta$-galactoside (5.9 mg), Kaempferol-3O- $\beta$-D-glucoside $(6,14 \mathrm{mg})$ and Kaempferol-7-O- $\beta$-D-glucoside (7.12mg). Fraction F6 was subjected to column chromatography (CC) and eluted with $n$-hexane/AcOEt mixture with increasing polarityto yield Trans-Tiliroside $(8.18 \mathrm{mg})$.

\section{Antimicrobial activity of Extracts/Fractions and Compounds Tested microorganisms}

The micro organisms include bacteria (Staphylococcus aureus NR46374, Klepsiella pneumonia NR41916, Salmonella enterica NR13555, Shigella flexineri NR518) and fungal strains (Candida albicans ATCC P37037, Candida krusei ATCC 6258, Candida parapsilosis ATCC 22019) originally obtained from BEI resources and American Type Culture Collection respectively. The organisms were maintained on agar slope at $4{ }^{\circ} \mathrm{C}$ and sub-cultured for $24 \mathrm{~h}$ and $48 \mathrm{~h}$ respectively for bacteria and yeasts before use.

\section{Preparation of stock solution of plants crude extracts, fractions and compounds}

The different stock solution of crude extracts, fractions and compounds were prepared by dissolving $2 \mathrm{mg}$ in $1 \mathrm{~mL}$ of DMSO $10 \%$ for a final concentration of $2 \mathrm{mg} / \mathrm{mL}$. Reference antibiotics were prepared in the same condition by dissolving 512 $\mu \mathrm{g}$ of Fluconazole (Sigma Aldrich) and $2 \mathrm{mg}$ of Chloramphenicol and Ampicillin (Sigma Aldrich) in $1 \mathrm{~mL}$ of DMSO10 \% to yield $512 \mu \mathrm{g} / \mathrm{mL}$ and $2 \mathrm{mg} / \mathrm{mL}$ respectively. After preparation, the different stock solutions were sterilized with $0.20 \mu \mathrm{M}$ Syringe Filter and store at $-20^{\circ} \mathrm{C}$ before use.

\section{Antifungal activity}

\section{Determination of minimal inhibitory concentration (MIC) and minimal fungicidal concentration (MFC)}

The minimum inhibitory concentration (MIC) was determined according to Clinical Laboratory Standards Institute M27-A3 microdilution method (CLSI, 2008) using (12 x 8 wells) microtitre plates. In the well of the first line (1-12), $100 \mu \mathrm{L}$ of RPMI 1640 (Sigma Aldrich) medium were introduced and $100 \mu \mathrm{L}$ in the other well of the plates. Later on, $100 \mu \mathrm{L}$ of stock solution of crude extracts, fractions and compounds were added to the first well. The medium and extract/compound in the first well were mixed thoroughly before transferring $100 \mu \mathrm{L}$ of the resultant 
mixture to the well of the second line. Serial two-fold dilutions of the test samples were made and $100 \mu \mathrm{L}$ of inoculum standardized at $2.5 \times 10^{4}$ cells $/ \mathrm{mL}$ were introduced in the entire well containing the test substances except the column of blank which constitute the sterility control. The concentrations ranged from 0.000488 to 0.5 $\mathrm{mg} / \mathrm{mL}$ and from $1.25 \mu \mathrm{g} / \mathrm{mL}$ to $128 \mu \mathrm{g} / \mathrm{mL}$ for crude extracts/fractions/compounds and fluconazole respectively. After 48 hours of incubation at $37^{\circ} \mathrm{C}$, the turbidity was observed as indication of growth. MIC was defined as the lowest concentration inhibiting the growth of yeasts. The MFC was determined by transferring $50 \mu \mathrm{L}$ aliquots of the clear wells into $150 \mu \mathrm{l}$ of freshly prepared broth medium and incubating at $37^{\circ} \mathrm{C}$ for 48 hours. The MFC was regarded as the lowest concentration of test sample which did not produce turbidity as above, indicating no microbial growth. All tests were performed in triplicates.

\section{Antibacterial activity \\ Determination of minimal inhibitory concentration (MIC) and minimal bactericidal concentration (MBC)}

The MIC was determined according to Clinical laboratory Standards Institute (CLSI) M38-A microdilution method (CLSI, 2008) using 96 wells microtitre plates. 100 $\mu \mathrm{L}$ of Muller Hinton Broth (Lab M Limited Topley House) was introduced in the wells of column $1(1 \mathrm{~A}-1 \mathrm{H})$, and $100 \mu \mathrm{L}$ in the remaining wells. Later on, $100 \mu \mathrm{L}$ of stock solutions of plants extracts/compounds at $2 \mathrm{mg} / \mathrm{mL}$ were added to the first well. The medium and sample in the first well were mixed thoroughly and serially diluted by transferring $100 \mu \mathrm{L}$ from wells of column 1 to wells of column 2 , and so on till column 11 .
Thereafter, $100 \mu \mathrm{L}$ of the inoculums were introduced in each well containing the test substances. The wells of column 12 are used as blank. The concentration of substances range from $0.5 \mathrm{mg} / \mathrm{mL}$ to $0.000488 \mathrm{mg} / \mathrm{mL}$. After an incubation period at $37^{\circ} \mathrm{C}$ for 24 hour, turbidity was observed as indication of growth. Thus, the lowest concentration inhibiting the growth of bacteria was recorded as the MIC. The MBC was determined by transferring $50 \mu \mathrm{L}$ aliquots of the clear wells into $150 \mu \mathrm{l}$ of freshly prepared broth medium and incubating at $37^{\circ} \mathrm{C}$ for 24 hours. The $\mathrm{MBC}$ was regarded as the lowest concentration of test sample which did not produce turbidity as above, indicating no microbial growth. All tests were performed in triplicates.

\section{RESULTS}

\section{Fractionation and isolation of compounds}

The extracts from Dissotis perkinsiae, were fractionated by silica gel column chromatography to afford eight compounds (1-7) identified asUrsolic acid (1) (Seebacher et al., 2003); Sitosterol- $\beta$-D-glucoside (2) (Mizanur et al.,2009; Nono et al., 2014; Mai et al., 2012); Isoquercitrin (3) (Mortada et al., 2010 ; Danielly et al., 2007; Agus et al., 2014); Quercetin-3-O- $\beta$ galactoside (4) (Mortada al. 2010; (Wang Z et al., 1998 ; Chen L et al., 2005);Kaempferol-3-O- $\beta$-D-glucoside (5)(Ferreira et al., 2010; Abdelaaty et al., 2005); Kaempferol-7-O- $\beta$-D-glucoside (6) (Xiaoshu Zhang et al., 2013); Trans-Tiliroside(7) (Mekhelfi et al., 2014). The structures of the compounds were determined by analysis of their NMR data and comparison with those reported in the literature (Figure 1).
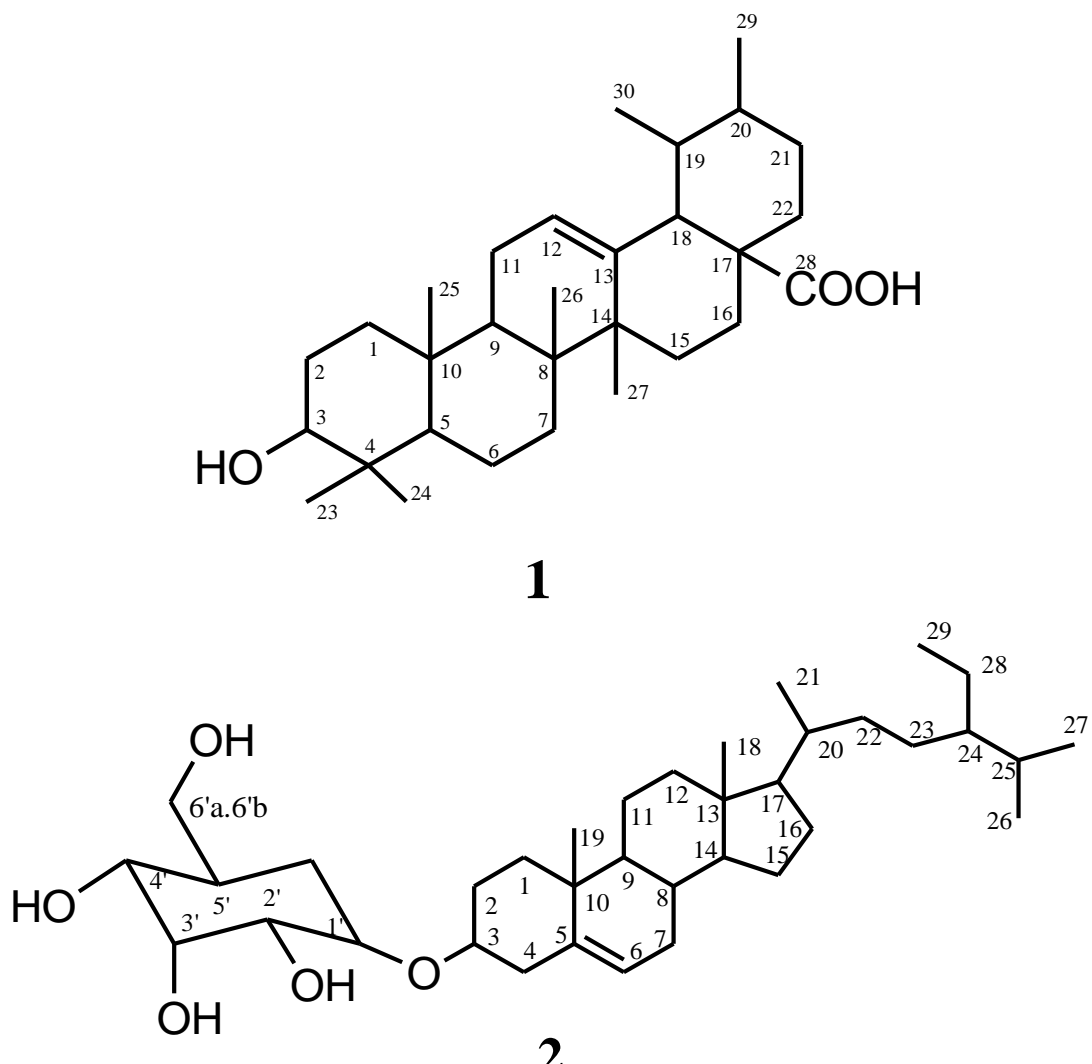
<smiles></smiles><smiles></smiles><smiles>O=c1c(O)c(-c2cccc(O)c2)oc2cc(O[C@@H]3O[C@@H]4[C@H](O)[C@@H](O)[C@H]3[C@@H](O)[C@H]4O)cc(O)c12</smiles>

5

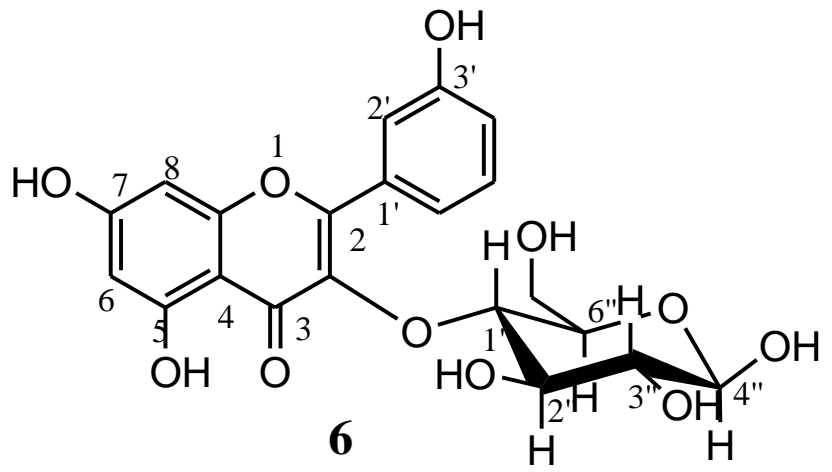

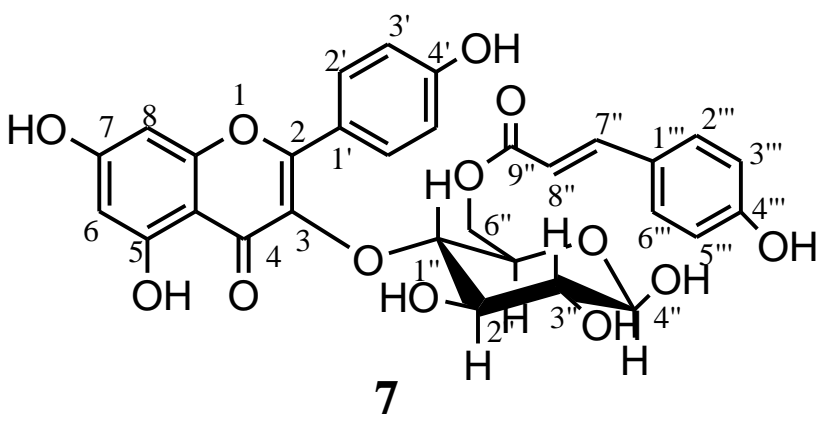

Fig. 1: Compounds isolated from Dissotis perkinsiae.

\section{Antimicrobial results}

The results of antibacterial and antifungal activities of extracts, fractions and compounds from Dissotis perkinsiae are presented in tables 1, 2, 3 and 4. The results indicate that the MIC vary from $>0.5$ to $0.00078 \mathrm{mg} / \mathrm{mL}$ on yeasts and from $>0.5$ to 0.25 $\mathrm{mg} / \mathrm{mL}$ on bacteria. This inhibition was found to be extracts, compounds and microorganism dependent. The activity of ethyl acetate and hexane fractions were better than crude extract on the three yeast species. Compounds 2 (Sitosterol- $\beta$-D-glucoside) was the most active with the broad spectrum. It is the most active on $C$. albicans and $C$. parapsilosis while, compounds 6 (Kaempferol-7O- $\beta$-D-glucoside) was the most active on $C$. krusei. The antiyeats activity of Sitosterol- $\beta$-D-glucoside and Kaempferol-7-O- $\beta$-Dglucoside were better than fluconazole $(0.032 \mathrm{mg} / \mathrm{mL})$ on $C$. parapsilosis (MIC $0.0078 \mathrm{mg} / \mathrm{mL}$ ) and C. krusei $(0.0039 \mathrm{mg} / \mathrm{mL}$ ) respectively. Sitosterol- $\beta$-D-glucoside and Kaempferol-7-O- $\beta$-Dglucoside exhibited fungicidal activity on the tested microorganisms, high light the ability of these compounds to kill Candida species. On bacteria, the activity of crude extract was better than fractions. Compounds 2 and compounds 7 showed weak inhibitotry activity respectively against S.enterica and $S$. aureus with MIC value of $0.5 \mathrm{mg} / \mathrm{mL}$. This inhibitory effect was less than activity of Chloremphenicol and Ampicillin (0.000488 $\mathrm{mg} / \mathrm{mL})$. 
Table 1: MIC of extract, fractions and compounds on yeasts strains $(\mathrm{mg} / \mathrm{mL})$.

\begin{tabular}{|c|c|c|c|c|c|c|c|c|c|c|}
\hline \multirow{3}{*}{ Microorganisms } & \multicolumn{10}{|c|}{ Minimal Inhibitory Concentration } \\
\hline & \multicolumn{3}{|c|}{ Extracts } & \multicolumn{5}{|c|}{ Compounds } & \multicolumn{2}{|r|}{ Reference } \\
\hline & DP & DPAE & DPH & 1 & 2 & 3 & 4 & 6 & 7 & Fluconazole \\
\hline C. albicans $\mathrm{P} 37037$ & $>0.5$ & 0.25 & 0.5 & 0.5 & 0.125 & $>0.5$ & 0.5 & 0.5 & $>0.5$ & 0.032 \\
\hline C. krusei 6258 & $>0.5$ & 0.5 & 0.5 & $>0.5$ & 0.0625 & 0.25 & 0.125 & 0.0039 & 0.25 & 0.032 \\
\hline C. parapsilosis 22019 & $>0.5$ & 0.5 & 0.5 & $>0.5$ & 0.0078 & $>0.5$ & $>0.5$ & 0.5 & 0.25 & 0.032 \\
\hline
\end{tabular}

Table 2: MFC of extract, fractions and compounds yeasts strains $(\mathrm{mg} / \mathrm{mL})$.

\begin{tabular}{|c|c|c|c|c|c|c|c|c|c|c|}
\hline \multirow{3}{*}{ Microorganisms } & \multicolumn{10}{|c|}{ Minimal Fongicidal Concentration } \\
\hline & \multicolumn{3}{|c|}{ Extracts } & \multicolumn{5}{|c|}{$\begin{array}{c}\text { Compounds } \\
\end{array}$} & \multicolumn{2}{|r|}{ Reference } \\
\hline & DP & DPAE & DPH & 1 & 2 & 3 & 4 & 6 & 7 & Fluconazole \\
\hline C. albicans $\mathrm{P} 37037$ & $>0.5$ & $>0.5$ & $>0.5$ & $>0.5$ & 0.5 & $>0.5$ & $>0.5$ & 0.5 & $>0.5$ & 0.032 \\
\hline C. krusei6258 & $>0.5$ & $>0.5$ & $>0.5$ & $>0.5$ & 0.25 & $>0.5$ & $>0.5$ & 0.0312 & $>0.5$ & 0.032 \\
\hline C. parapsilosis 22019 & $>0.5$ & $>0.5$ & $>0.5$ & $>0.5$ & 0.0312 & $>0.5$ & $>0.5$ & 0.5 & $>0.5$ & 0.032 \\
\hline
\end{tabular}

DP: Methanol/dichloromethane extract of leaves of Dissotis perkinsiae; DPAE: Ethylacetate fraction from DP extract; DPH: Hexane fraction from DP extract;

Ursolic acid (1); Sitosterol- $\beta$-D-glucoside (2); Isoquercitrin (3); Quercetin-3-O- $\beta$-galactoside (4); Kaempferol-7-O- $\beta$-D-glucoside (6); Trans-Tiliroside (7).

Table 3: MICof extract, fractions and compounds on bacteria strains $(\mathrm{mg} / \mathrm{mL})$.

\begin{tabular}{|c|c|c|c|c|c|c|c|c|c|c|c|}
\hline \multirow{3}{*}{ Microorganisms } & \multicolumn{11}{|c|}{ Minimal Inhibitory Concentration } \\
\hline & \multicolumn{3}{|c|}{ Extracts } & \multicolumn{5}{|c|}{ Compounds } & \multicolumn{3}{|c|}{ Reference } \\
\hline & DP & DPAE & DPH & 1 & 2 & 3 & 4 & 6 & 7 & Choremphenicol & Ampicillin \\
\hline S. aureus NR46374 & 0.25 & 0.25 & 0.5 & $>0.5$ & $>0.5$ & $>0.5$ & $>0.5$ & $>0.5$ & 0.5 & 0.000488 & 0.000488 \\
\hline K.рnеuтопіа NR41916 & 0.5 & $>0.5$ & $>0.5$ & $>0.5$ & $>0.5$ & $>0.5$ & $>0.5$ & $>0.5$ & $>0.5$ & 0.0039 & 0.000488 \\
\hline S.enterica NR13555 & $>0.5$ & $>0.5$ & $>0.5$ & $>0.5$ & 0.5 & $>0.5$ & $>0.5$ & $>0.5$ & $>0.5$ & 0.000488 & 0.000488 \\
\hline
\end{tabular}

Table 4: MBF of extract, fractions and compounds on bacteria strains $(\mathrm{mg} / \mathrm{mL})$.

\begin{tabular}{|c|c|c|c|c|c|c|c|c|c|c|c|}
\hline \multirow{3}{*}{ Microorganisms } & \multicolumn{11}{|c|}{ Minimal Bactericidal Concentration } \\
\hline & \multicolumn{3}{|c|}{ Extracts } & \multicolumn{5}{|c|}{ Compounds } & \multicolumn{3}{|c|}{ References } \\
\hline & DP & DPAE & DPH & 1 & 2 & $\mathbf{3}$ & 4 & 6 & 7 & Choremphenicol & Ampicillin \\
\hline S. aureus NR46374 & $>0.5$ & $>0.5$ & $>0.5$ & $>0.5$ & $>0.5$ & $>0.5$ & $>0.5$ & $>0.5$ & $>0.5$ & 0.000488 & 0.000488 \\
\hline К.рnеuтопіа NR41916 & $>0.5$ & $>0.5$ & $>0.5$ & $>0.5$ & $>0.5$ & $>0.5$ & $>0.5$ & $>0.5$ & $>0.5$ & 0.0039 & 0.000488 \\
\hline S.enteric NR13555 & $>0.5$ & $>0.5$ & $>0.5$ & $>0.5$ & 0.5 & $>0.5$ & $>0.5$ & $>0.5$ & $>0.5$ & 0.000488 & 0.000488 \\
\hline S.flexineri NR518 & $>0.5$ & $>0.5$ & $>0.5$ & $>0.5$ & $>0.5$ & $>0.5$ & $>0.5$ & $>0.5$ & $>0.5$ & 0.000488 & 0.000488 \\
\hline
\end{tabular}

DP: Methanol/dichloromethane extract of leaves of Dissotis perkinsiae; DPAE: Ethylacetate fraction from DP extract; DPH: Hexane fraction from DP extract;

Ursolic acid (1); Sitosterol- $\beta$-D-glucoside (2); Isoquercitrin (3); Quercetin-3-O- $\beta$-galactoside (4); Kaempferol-7-O- $\beta$-D-glucoside (6); Trans-Tiliroside (7).

\section{DISCUSSION}

Ursolic acide, quercetin, $\beta$-sitosterol gucoside, were previously reported from the same plant by (Ndjateu et al., 2014).

The antimicrobial activity of Sitosterol- $\beta$-D-glucoside and Kaempferol-7-O- $\beta$-D-glucoside can be explained by the substitution of hydroxyl group in the $\beta$-Sitosterol and Kaempferol skeletons a glucoside group which enhance their activity. In fact, the glucoside group is known to be responsible for antimicrobial activity due to their ability to form a complex with cell membrane of microorganisms, and thus, inhibiting microbial growth (Cowan, 1999). The difference in activity of the tested compounds on yeasts and bacteria can be explained by genetic distance or specific mechanisms of action on the cell membrane of the microorganisms. In the same way as many antifungal drugs, these compounds could act on ergosterol biosynthesis. Absent in bacteria, ergosterol isone of the key components of the fungal cell membrane and the main sterol of yeasts and other fungi. It is necessary for the growth of cells and normal membrane function. It serves as a bioregulator of membrane fluidity, asymmetry and membrane integrity and contributes to the proper function of membrane-bound enzymes. Thus, the inhibition of ergosterol biosynthesis lead to the death of fungi cell (Lupetti et al., 2002).

\section{CONCLUSION}

The results provide justification for the use of Dissotis perkinsiae in folk medicine to treat various diseases. This study might be considered as a prelude to discover new antimicrobial agents to the problematic pathogenic bacteria and fungi. Moreover, the broad spectrum activity of isolated compounds as Sitosterol- $\beta$ D-glucoside gives the opportunity for possible discovery of new, effective components for downstream clinical development. Whereas, many studies have to be carry out to obtain insight into its mode of action and antifungal activity.

\section{ACKNOWLEDGEMENTS}

Bruno Bakang Tchebemou is grateful respectively to Dr. Frederic NANA and Mr. Victor Nana (Plant taxonomist) of the Cameroon National Herbarium (HNC). 


\section{REFERENCES}

Abdelaaty A,Shahat, Naglaa M, Nazif, Nahla S,Abdel A, Luc P, Arnold JVL. Flavonoids from cressa cretica. Quatar Univ Scie J 2005; 25:72-77

Agus S, Sanro T .Isolation of hyperperoside and Isoquercitrin from camellia sasanqua as Antioxydant Agents.Pakistan Journal of Biological Sciences 2014; 17(8):999-1006.

Brandão, HN, David JP, Couto RD, Nascimento JAP, David JM. Química e Farmacologia de Quimioterápicos Antineoplásicos Derivados de Plantas. Quim. Nova 2010; 33: 1359-1369.

Chen L, Du LJ, Ding Y. China J Chi Materia Medica 2005; 30: 1340-1342.

Clinical Laboratory Standard Institute, Reference Method for Broth Dilution Antifungal Susceptibility Testing of Yeasts, Approved standard, third edition M27- A3, Wayne, PA: Clinical Laboratory Standard Institute, 2008.

Clinical Laboratory Standard Institute, Reference Methods for Dilution Antimicrobial Susceptibility tests for Bacteria that grow Aerobically; Approved Standard-Seventh Edition (2006). Clinical Laboratory Standard Institute, 2008.

Cowan MM. Plant products as antimicrobial agents. Clin Microbiol Rev 1999; 12: 564-582.

Cragg GM, Newman DJ, Snader KM.Natural products in drug discovery and development. Journal of Natural Products 1997; 60: 52-60.

Danielly ADC, Davi AES, Aline CC, Marcos AADM, Julianeli TDL, José MSC, Bagnólia ADS, Maria FA and Maria FVS.: Chemical constituents from bakeridesia pickeliimonteiro (malvaceae) and the relaxant activity of kaempferol-3-O- $\beta$-D-(6"-e-p-coumaroyl) glucopyranoside on guinea-pig ileum.quim Nova 2007; 30(4): 901-903.

Ghareeb. Bio-guided isolation and structure elucidation of antioxidant compounds from the leaves of ficussycomorus. Pharmacology online2010; 3: 317-332.

Haxaire C. Phytothérapie et Médecine Familiale chez les Gbaya-Kara (République Centrafricaine). Thèse de doctorat, Université de Paris, Fac. Pharmacie 1979: 320p.

Hutchinson J, Dalziel J. Melastomataceae. In: Flora of West Tropical Africa, Crown Agents for Oversea Governments and Adminitrations, London 1954: 295p.

Johanna K, Harald F, Elfriede P, Michael H. Historical and modern plant uses-the example of the Chorti'Maya and Ladinos in Eastern Guatemala. Journal of Pharmacy and Pharmacology 2005; 57:1127-1152.

Jorge FS, Ferreira , Devanand L, Luthria , Tomikazu S, Arne H. Flavonoids from Artemisia annuaLas Antioxidants and Their Potential Synergism with Artemisinin against Malaria and Cancer. Molecules2010; 15: $3135-3170$

Loigier HA. Descriptive flora of Puerto Rico and Adjacent islands. Spermaphyta 1994:1-3.

Lupetti A, Danesi R, Campa M, Del Tacca M, Kelly S: Molecular basis of resistance to azole antifungals. Trends Mol Med 2002; 8: $76-81$.

Mai AO, Wafaa HB, Hassan, Mohammad S. Ahmad, Adnan J, Al-Rehaily. Phytochemical and biological studies of Solanum schimperianum Hochst. Saudi Pharmaceutical Journal 2012; 20: 371-379.
Maluma, V. Les antherotomadissotis (inl. heterotis), Melastomataceae endémiques

d'Afrique Centrale. Revue de Taxonomie et de Nomenclature Botaniques $2005: 1-18$.

Mekhelfi T, Kerbab K, Guella G, Zaiter L, Benayache S, and BenayacheF.Der Pharmacia Lettre 2014; 6(1):152-156.

Mizanur RSM, Zinnat AM, Amzad HM. Isolation and characterization of $\beta$-sitosterol-D-glycoside from petroleum extract of the leaves of Ocimum sanctumL.As J Food Ag-Ind2009; 2(01): 39-43

Mortada MES, Maher AAM, Hanan AKEN, Sayed AHET, Eman AEW, Mosad AG. Bio-guided isolation and structure elucidation of antioxidant compounds from the leaves of ficussycomorus. Pharmacologyonline 2010; 3: 317-332.

Ndjateu FST, Rolande BNT, Blaise KN, Maurice DA, Hippolyte KW, Mathieu T, Pierre T, Jacobus NE. Antimicrobial and antioxidant activities of extracts and ten compounds from three Cameroonian medicinal plants: Dissotis perkinsiae (Melastomaceae), Adenocarpus mannii (Fabaceae) and Barteria fistulosa (Passifloraceae). South African Journal of Botany 2014; 91: 37-42.

Newman, DJ, Cragg GM, Snader, KM. Natural products as sources of new drugs over the period 1981-2002. J. Nat. Prod 2003; 66:1022-1037.

Nono RN, Barboni L, Teponno RB, Quassinti L, Bramucci M, Vitali LA, Petrelli D,

Lupidi G, Tapondjou AL. Antimicrobial, antioxidant, antiinflammatory activities and phytoconstituents of extracts from the roots of Dissotis thollonii Cogn. (Melastomataceae). South African Journal of Botany 2014; 93:19-26.

Seebacher W, Simic N, Weis R, Saf R, Kunert O. Complete assignments of ${ }^{1} \mathrm{H}$ and ${ }^{13} \mathrm{C}$ NMR resonances of oleanolic acid, $18 \alpha-$ oleanolic acid, ursolic acid and their 11-oxo derivatives. Magnetic Resonance in Chemistry 2003; 41: 636-638.

Wang Z, He ZS, Chin. Tradit Herb Drug 1998; 29: 577-579.

Xiaoshu Z, Zhenting L, Xiuli B, Jingxin L, Wei L, Yuqing Z. Flavonoids and its derivatives from Callistephus Chinensis flowers and their inhibitory activities against $\alpha$-glucosidase. Exclijournal 2013; 12:956-966.

How to cite this article:

Bruno TB, Oscar NDY, Désiré S, Ernestine ZNT, Marie TKR, Lazare SS, Fabrice FB, Bernd S, Barthélémy N. Chemical Constituents of Dissotis Perkinsiae (Melastomaceae) and Their Antimicrobial Activity. J App Pharm Sci, 2016; 6 (08): 096-101. 